\title{
THE OCCURRENCE AT PLYMOUTH OF THE OPISTHOBRANCH AKERA BULLATA, WITH NOTES ON ITS HABITS AND RELATIONSHIPS
}

\author{
By J. E. Morton \\ and N. A. Holme \\ The Plymouth Laboratory \\ (Plate I and Text-figs. I and 2)

\section{INTRODUCTION AND ECOLOGY}

Department of Zoology, Queen Mary College, University of London

Akera bullata O. F. Müller is a tectibranch mollusc having a coiled external shell and a foot with lateral extensions used for swimming. At certain times of the year it swims actively, as was observed by Donovan, who writes that it 'sports in its watery element with all the liveliness of a butterfly, and formed a pleasing object when kept alive in a glass of sea water' (quoted by Montagu, I803). Although sometimes abundant locally, it is not a mollusc often taken by the collector, even though it is a conspicuous object when swimming.

The first record of this species from Plymouth was the discovery of large numbers in a sea-water tank in the Naval Dockyard at Devonport, in April 1954. It has been recorded from a number of places in the British Isles, and ranges from Norway to the Mediterranean (Forbes \& Hanley, I853).

Two variants of the original species have been described: var. nana Jeffreys is a small form which was dredged in the Shetlands, and var. farrani Norman, a giant form from a locality in Ireland (Norman, I890, p. 68). Since these so-called varieties apparently differ only in size, they would seem to be of doubtful validity. The specimens taken at Devonport were the normal form described by Müller, and listed as $A$. bullata bullata Müller by Winckworth (1932).

The specimens were found in an oval concrete tank, some $33.5 \mathrm{~m}$ long, $23 \mathrm{~m}$ broad, and $2.5 \mathrm{~m}$ deep. Water is continually drawn from the tank for use in the Dockyard, the level dropping perhaps $20-30 \mathrm{~cm}$ during the day. The tank is topped up daily with water drawn from the lower part of the Tamar estuary, opposite St John's Lake. The tank is some distance above sea level, and about a quarter of a mile from the river.

The sea-water intake is about 2 miles from the mouth of the Tamar, and at this point the surface salinity varies around $30 \%$ (Milne, 1938, p. 538). A single sample from the tank on I4 April 1954 had a salinity of $32.95 \%$ 
(density $\mathrm{I} \cdot 02470$ at $\mathrm{I} 3 \cdot 6^{\circ} \mathrm{C}$ ), the temperature being $\mathrm{Ir} \cdot 6^{\circ} \mathrm{C}$. Salinity variations must be less sudden than in the estuary, since only a small proportion of the total volume is renewed daily.

The vertical sides of the tank were covered with a thick growth of green algae, mainly Ulva, and in the summer of 1954 there was also much filamentous green alga, both at the bottom and floating on the surface. There was a thin layer of mud on the bottom, but the water was usually quite clear, except just after pumping.

Apart from Akera the fauna was sparse, a few gobies, mysids, amphipods, and ascidians being taken. There were also two or three medium-sized fish, possibly pollack (Gadus pollachius L.). Apart from the abundance of algal food, Akera may have been favoured by the absence of predators. Although apparently distasteful to some fish, it has been found in the stomach of the flounder (Jeffreys, I867, p. 432).

The outflow of water from the tank is evidently not so great as to sweep away considerable numbers of Akera larvae, as young specimens spawned in the tank were abundant in the summer of 1954 .

The swimming habit of this animal has often been noted, and a detailed description of swimming movements is given below. On the first visit, on I4 April 1954, both adults and young were swimming in fair numbers, although there were always many more crawling on the sides and bottom of the tank. Since most individuals would swim after capture, it is fairly safe to say that at that time all, or nearly all, those in the tank were swimming intermittently. In the laboratory, adults would sometimes swim for periods of half an hour or more, and the young seemed capable of swimming for even longer periods. Swimming may be initiated by disturbing the animals, but individuals also swim spontaneously from time to time.

Swimming mainly takes place in the spring, which is the peak spawning period (cp. Guiart, I90I, p. 47). In April I954 adults were copulating and spawning in the laboratory, and much spawn was found in the Devonport tank. Akera appears to have an extended breeding period, as a little spawn was found as late as I3 July, and small specimens, presumably spawned earlier in the year, were common in April. Thorson (1946) records that in Denmark egg-masses are found throughout the summer, indicating a rather later spawning season than at Plymouth.

On 29 April fewer adults and young were swimming than on the I4th. On the next visit, on 17 June, many young were crawling over the algae, but adults were very rare, and no Akera were seen swimming in spite of good visibility in the tank. Some of the young taken on this date did swim in a plunger jar in the laboratory, however, a few days later. On I3 July there were still none swimming, and young stages again predominated.

Observations are being continued, but the evidence so far collected indicates that the species is annual, growing to maturity and spawning after a 
year, after which the majority die. Swimming, both of adults and young, is more or less confined to the spring, and may perhaps be correlated with the breeding season. Akera may occasionally swim in the summer.

Akera normally lives on mud flats, among weeds or Zostera, but none have been recorded from Plymouth, nor in the Yealm and Salcombe estuaries (Marine Biological Association, I93I), where conditions would appear to be suitable. It is not recorded from Torbay (Jukes-Browne, I9I0) or the Exe estuary (Allen \& Todd, I902, and observations by N. A. H. during 1946-47). The nearest records are from Falmouth and Helford, 40 miles to the west (Clark, I906, and personal communication from $\mathrm{Mr}$ R. Baird, who has found it in the $\mathrm{Fal}$ in recent years). It has been taken 70 miles to the eastward in the Fleet, Dorset, by Mr G. M. Spooner, and at Roscoff, 100 miles to the south, across the English Channel (Station Biologique de Roscoff, I95I). One or more specimens were evidently introduced to the tank via the inflow pipe, but there is no evidence as to their origin.

\section{EXTERNAL Form AND SWIMMING}

A description of the external features of Akera bullata has already been provided by Guiart (I9OI), showing the division of the body into two regionsa smaller, dorso-ventrally flattened head, connected by a narrow 'neck' to a larger, ovoid visceral mass. The spirally coiled shell is yellowish brown in colour and encloses the visceral mass and the mantle. The features of the shell are well described by Jeffreys (I867) and by Forbes \& Hanley (I853). In the sedentary posture, the neck and most of the visceral mass of the animal are concealed by the upgrowth of a pair of large, thin flaps, the parapodia, or 'wings' which are expansions of the ventral surface upon which Akera creeps. At their widest parts the wings overlap upon the dorsal surface, surrounding most of the body, so that the animal, when crawling fully extended, has a narrowly conical appearance, broadening behind, where the visceral hump and shell protrude from the parapodia. A long white filament, forming a grooved tentacle produced from the pallial margin, trails behind. In the crawling animal the right parapodium seems invariably to lie above the left, but when the parapodia come to rest between successive swimming movements, this arrangement is reversed, and it is the edge of the left parapodium which lies uppermost. A. bullata shows on the parapodia and ventral surface a ground colour of ashen brown or grey, closely spotted and blotched, as in an Aplysia, with greyish white. Inside the parapodia, and on the narrow 'neck' the colour is lighter and the head is streaked longitudinally with a series of broken lines of dark brown or black.

In crawling-which is its most frequent movement-Akera proceeds on the flattened ventral surface which is continuous with the parapodia. This surface is in no way marked off as a distinct sole, and is pigmented in the same way as the parapodia themselves. It is richly supplied with mucous glands and the 
animal appears often to secrete about itself a tube of slime, from which it may then emerge by crawling out in front. At times the head and the visceral mass may be almost completely retracted within the cloak formed by the parapodia, and the animal sits motionless, taking on a compact flask-shape.

The swimming movements-when first seen-come as a surprise (see Text-fig. I). They begin by the opening out of the parapodia, so as partly to display the body between them. The margins are then lifted up like a skirt and stand out freely from the body, while the anterior end of the animal rises first from the ground, so that the animal achieves an upright position, and sits making one or two tentative openings of the parapodia. The visceral mass can now be clearly seen below, like the clapper of a bell, as the parapodia are finally widely extended and the skirt is lifted high. As the edges of wings disengage the dorsal surface is also uncovered, and the skirt extends at right angles to the body, in the same plane as the creeping surface of the foot. The creeping surface is now presented uppermost, and forms a more rigid tract, terminating behind in a permanent point, while round it the flaps of the parapodia form a heart-shaped shield, with the edges slightly upcurved.

The skirt is now rapidly lowered, and its contraction against the water beneath it provides the motive power by which the animal leaves the ground and is lifted through the water. As the edges of the parapodia again come together, they enwrap the dorsal surface, the left one this time uppermost. Almost at once they are opened again and spread flat, to contract downwards in another effector stroke which carries the animal further upwards. After each swimming stroke, the animal loses way by sinking a short distance from the weight of the visceral hump, before the next movement of the wings carries it upwards in a renewed spurt. An average of forty-five strokes a minute was reckoned for one specimen at normal sea temperature. The movements have an extraordinary lightness and grace, and an impression of the swimming animal may be gained from the photographs (P1. I) made by Dr D. P. Wilson in the Plymouth laboratory.

\section{Digestive SysteM}

Since the descriptions of the alimentary canal given by Bergh (I900) and Guiart (I90I) are short and often inaccurate, an opportunity was taken to re-examine the gut, using living material and paying closer attention to functional aspects. In almost all its features the alimentary canal of Akera is entirely aplysioid, and the same is true of the mode of life. Akera is a grazer on green algae such as Ulva, or a deposit feeder on material already comminuted. The buccal mass does not need separate description from that of Aplysia, but a figure of the radula is provided here (Text-fig. $2 \mathrm{C}$ ). Each tooth row has a series of teeth typical of the grazing and raking form of radula seen in Aplysiomorpha. The radula resembles much less that of the Bullomorpha, whether the herbivorous forms or the much more modified carnivores. Into 

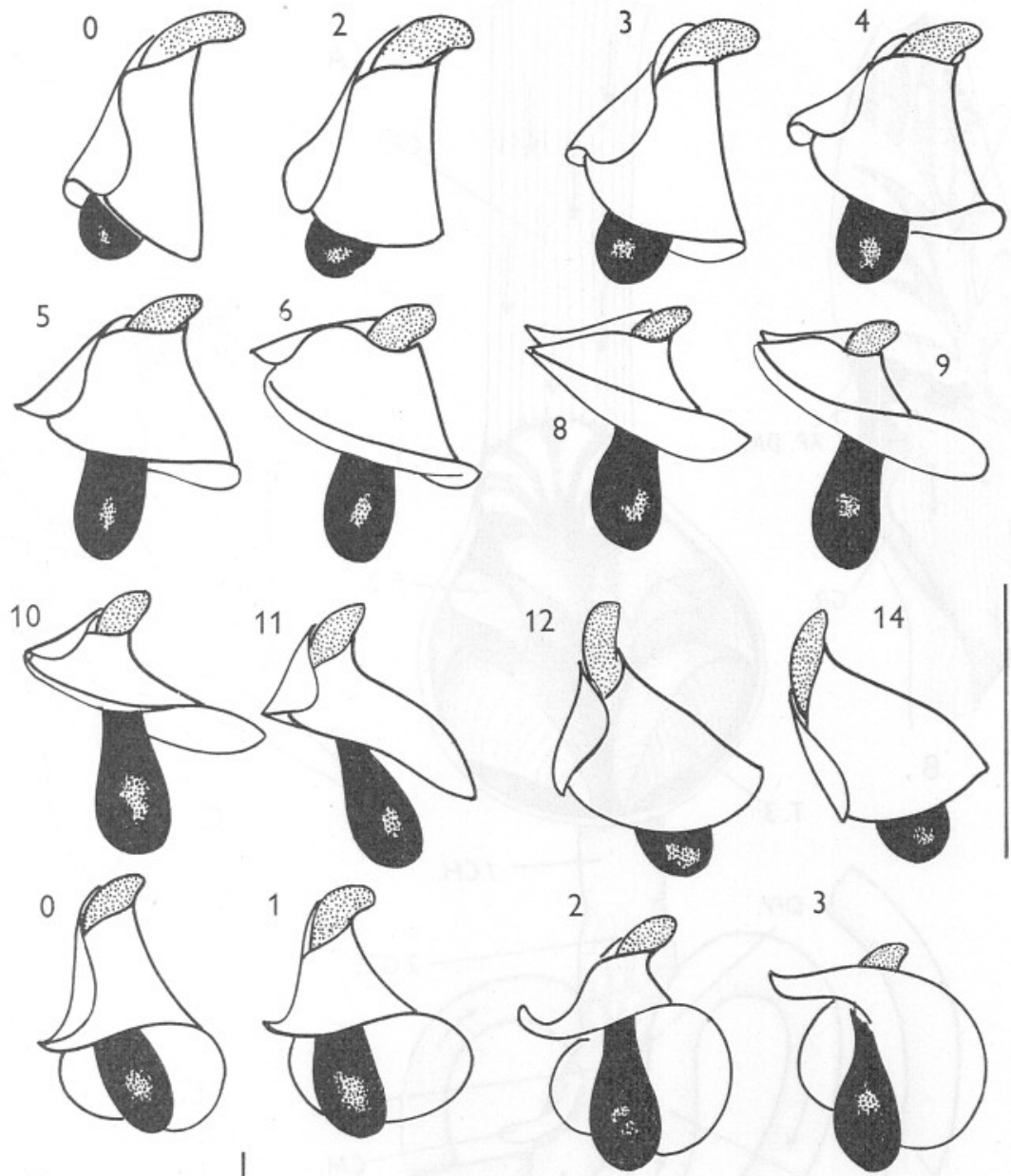

3
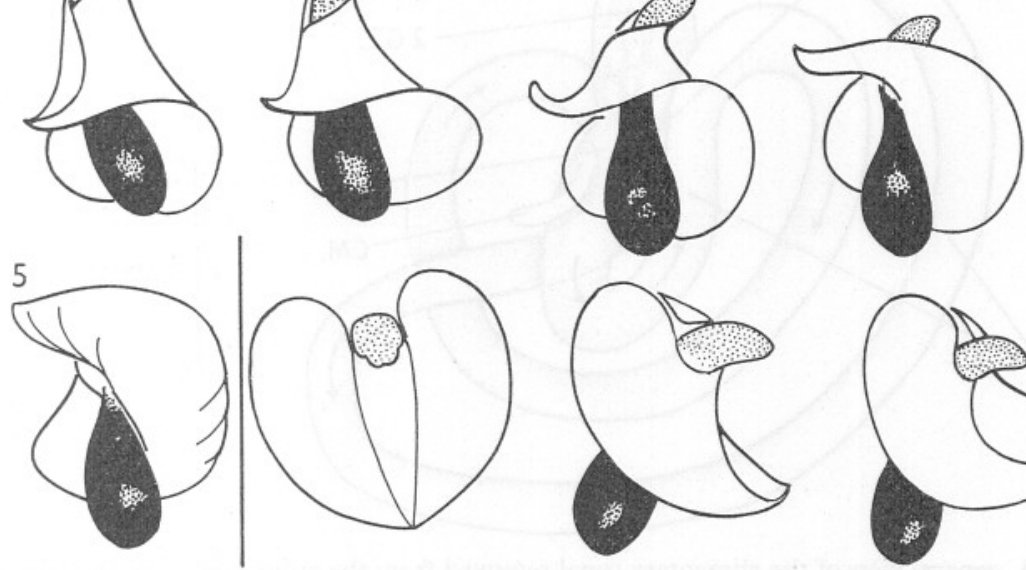

Fig. I. Outline diagrams to show the positions of the parapodia at successive stages during the swimming movements. The drawings are constructed from a cine-film record and those of the first three rows comprise a continuous sequence, with the time intervals in sixteenths of a second shown. Those of the fourth row and the first of the fifth row form another series, and the three final drawings are selected to show further views of typical swimming postures. 

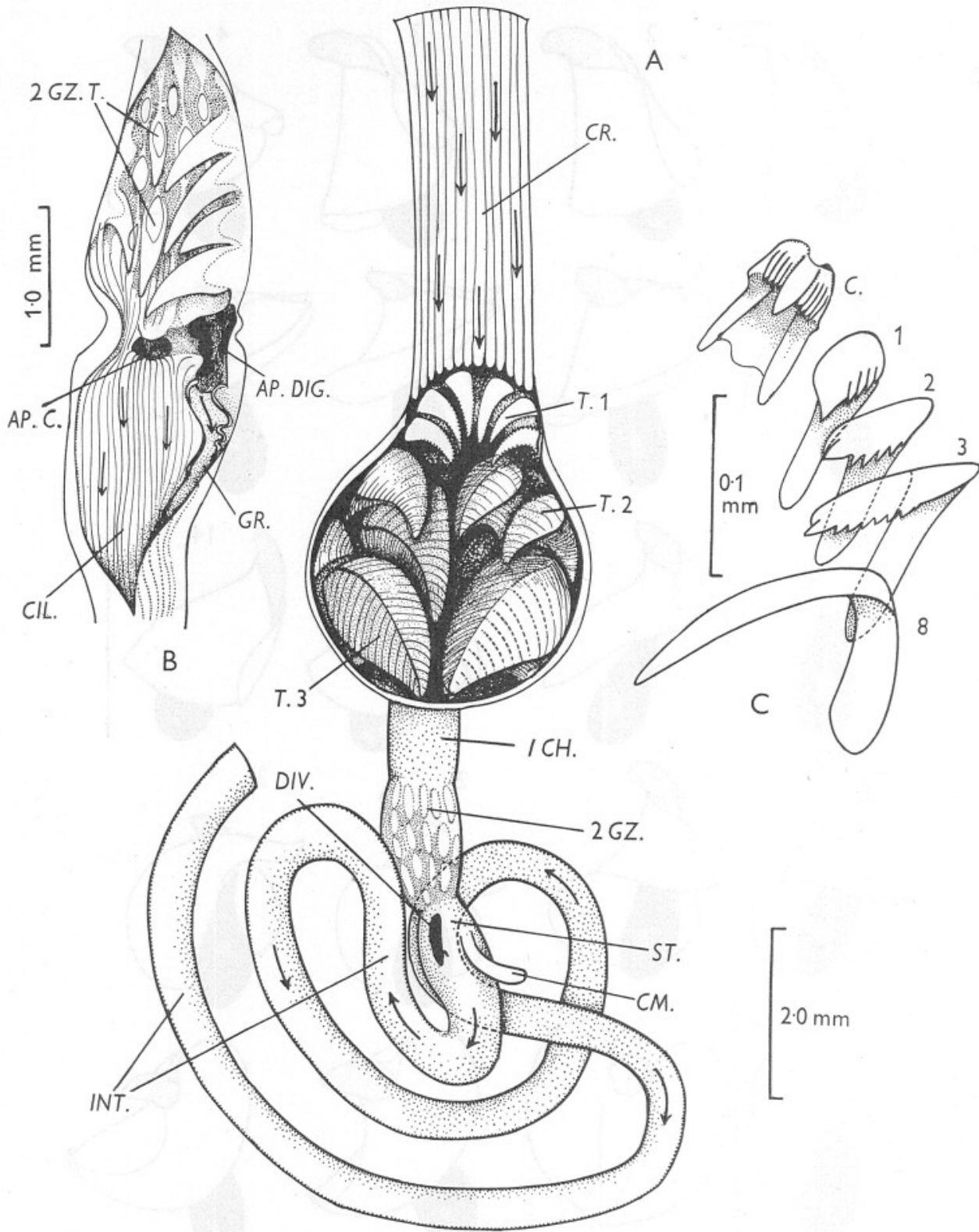

Fig. 2. A, general view of the alimentary canal removed from the animal with the buccal mass omitted, and the crop and first gizzard opened to illustrate their internal structure. $\mathrm{B}$, more detailed view of the second gizzard and the stomach, dissected to show internal structure. C, central $(C)$ and four of the marginal teeth (nos. I, 2, 3 and 8 ) of the most posterior tooth row of the radula. $A P$. C., aperture of the gastric caecum; $A P$. DIG., opening of the digestive diverticulum into the stomach; CIL., ciliated folds leading from the stomach into the intestine; $C M$., gastric caecum; CR., crop; $D I V$., position of digestive diverticulum; GR., groove leading into the intestine from the digestive diverticulum; 2 GZ., second gizzard; 2 GZ. T., teeth of the second gizzard; $I C H$., intermediate chamber between the first and second gizzards; INT., intestine; $S T$., stomach; T. I, $T .2 ; T .3$, teeth of the first, second and third tiers in the first gizzard. 
the buccal mass open a pair of long, strap-like salivary glands, with short tubular ducts. They are orange yellow in the living animal, and their histology resembles that of Aplysia, as described by Howells (1942).

The next regions of the gut are contained in the narrow, neck-like part of the body, and comprise a long, very distensible crop, and a large first gizzard, both of which are oesophageal. The crop is thin-walled and is thrown into a large number of fine longitudinal ridges. It is translucent white in colour, and the contained food-fine detritus and roughly chopped-up filaments of algae-shows through its wall. The shape of the crop varies greatly, according to the position of food passing through it. It is capable of very strong peristaltic movements, so that temporary constrictions and bulges are likely to appear along its course. At times it appears like a fat sac, at others it is a narrow tube of uniform width. As well as being muscular and peristaltic, the crop is strongly ciliated, and-apart from the intestine-it is the only part of the gut where cilia appear to play an important role. All beat strongly in the same direction, along the ridges and furrows towards the first gizzard.

The first gizzard is pyriform in shape, and extremely firm-walled (see Text-fig. 2A). At its narrow anterior end the ciliated folds of the crop end abruptly, and a food string containing coarse pieces of algae and debris passes into the mill formed by the series of gizzard teeth. These teeth are arranged in three tiers, the largest ones comprising a set of four at the posterior end of the gizzard. These four are massive and broad-based, each consisting of a thick shell of cuticle applied to a strong boss of the epithelium. They are roughly pyramidal in shape, but slightly beaked so that their blunt-pointed tips, which meet at the centre of the gizzard are directly backwards towards the exit. The next tier of teeth are also four in number, slightly smaller and alternating with the posterior teeth. Their tips are sharper and much more strongly beaked, directed backwards. The teeth of the most anterior tier, immediately inside the entrance to the gizzard comprise a circlet of six to eight. They are small and slender, and form a strainer through which the food passes before being engaged and crushed between the tips of the larger teeth.

The food leaving the gizzard forms a soft, greyish green cord, much finer in consistency than when it was received from the crop. Behind the gizzard lies a smaller region of the gut, narrow and not toothed, forming an intermediate chamber by which the first gizzard communicates with the second gizzard. This intermediate chamber has a longitudinally ridged wall, and is contractile, though not strongly muscular. So far as could be made out from living material, it is not ciliated. Behind it the gut opens through a 'diaphragm' of muscle and connective tissue, by which the organs lying within the head and 'neck' are separated from those of the visceral mass. Behind the diaphragm the second gizzard opens by a slight constriction from the intermediate chamber. The second gizzard is a great deal smaller than the first, and its walls are less muscular, though still strongly contractile. The teeth are here 
much smaller, the larger ones long and narrow and pointed backwards. They are hardly at all rigid, being for the most part soft and flexible to the touch. They fill most of the gizzard and form a series of papillae, serving not for the attrition of food but for filtering the stream of particles that is admitted to the stomach. These teeth are arranged in seven or eight longitudinal rows and their oboid bases are very clear externally, through the thin wall of the gizzard. One specimen had twenty-five, most of them small and short.

Text-fig. 2B illustrates the internal structure of the second gizzard, and its relation to the stomach, which properly speaking forms that part of the gut lying immediately behind the gizzard. It receives a single digestive diverticulum, and is equipped with a short, finger-shaped caecum. It is marked off in front by a constriction from the second gizzard, and merges gradually behind into the intestine. The walls of the stomach are ciliated and thrown into fine longitudinal folds, which continue backwards from the tooth-bearing folds of the second gizzard and run on into the intestine. Some of these folds lead out from the mouth of the caecum, which is ciliated internally and in most ways resembles that of Aplysia. The function of the caecum appears to be to fashion segments of the faecal string which pass from its opening directly into the intestine where they merge into a continuous rope. The opening of the caecum is connected by a shallow channel with the mouth of the digestive diverticulum, which lies a little to the side of it, and immediately behind the largest (posterior) tooth of the second gizzard. Leading backwards through the stomach from the diverticulum is a broad gutter, lined with strongly beating cilia, which enters the intestine and there loses its identity. Of the sorting area, gastric shield, and style sac, represented in bullomorphs (see Fretter, 1939; Fretter \& Graham, 1954) nothing remains in Akera.

The intestine describes a double loop, turning backwards after leaving the stomach, and running through the digestive gland to come to the surface on the right side. It then curves back again, running backwards above the stomach, around the visceral mass to the left. It finally runs forward and towards the mid-line as the rectum. The intestine is smooth-walled and finely ciliated, and carries a rope of fine, well-comminuted faeces. No peristaltic contractions could be observed, and the faecal string shows little sign of compression, or breaking into pellets. It issues free of the mantle cavity, breaking away from the anus at the edge of the mantle in large, irregular, coils.

\section{RELATIONSHIPS}

In the classification currently in use-that of Thiele (I93I) which has been adopted by Hoffmann (1938)-Akera is placed within the suborder Cephalaspidea (Bullomorpha) of the order Pleurocoela (Tectibranchia), in the Akeratidae. ${ }^{1}$ Two subfamilies are recognized by Thiele, namely the Akera-

The family name is correctly formed as Akeratidae, as in Pelseneer (I906), not Akeridae, as cited by Thiele. 
tinae, containing the single genus Akera, and the Cylindrobullinae. Pelseneer (I906) had previously placed the Akeratidae within the Bullomorpha, thereby reversing the decision of Guiart (I90I) who had put forward a number of reasons for considering these molluscs as more properly aplysiomorphs. From a further study of the structure of Akera bullata, it becomes clear that Guiart was right, and that Akera has many more characters in common with the Anaspidae (Aplysiomorpha) than with the Cephalaspidea (Bullomorpha). Of the features regarded by Pelseneer and later writers as diagnostic of the Bullomorpha, the following are the chief:

(i) The shell and pallial cavity are well developed and the gill is wholly or partly contained within the pallial cavity.

(ii) The head is devoid of apparent tentacles and is modified to form a diskshaped cephalic shield, used for digging into the sand.

(iii) The parapodia are continuous with the ventral sole of the foot.

(iv) The gizzard is either lacking, or single, with relatively few, sometimes calcareous plates.

(v) The visceral commissure is usually long.

In (ii) and in (iv) Akera is obviously unlike the bullomorphs. Although the eyes are reduced, and obvious tentacles are lost, the head remains unspecialized and with none of the modifications associated with the habit of burrowing beneath the soil. In the structure of the gut-and this is a region that has taken on distinctive specializations in all aplysiomorphs-Akera has already been shown to have all aplysioid features. There is a large first gizzard, a smaller second gizzard, both with numerous teeth, and a small gastric caecum. Typical bullomorphs have none of these (see Fretter, I939). The genitalia of Akera have not been investigated during this work, since they have already been dealt with in a comprehensive study by the late Dr Hilda Lloyd, which Dr Vera Fretter is preparing for publication. Dr Fretter has kindly allowed us to state that the reproductive system of Akera conforms in almost all respects to that of the aplysioids and has no distinctively bullomorph features. The mode of copulation with the formation of a chain of six or more individuals and the nature of the gelatinous egg-strings are also aplysioid features. The shell of the free-swimming veliger (see Thorson, I946) has the initial sinistral twist detectable in Bullomorpha but almost suppressed in the other aplysiomorphs.

In addition, the mantle cavity in Akera possesses the two typically aplysioid glands, an opaline gland occupying its floor, and a purple gland located in the roof, and secreting, as in Aplysia, a purple-coloured fluid. Finally, as completing the list of aplysioid resemblances, Dr G. Y. Kennedy and Dr H. G. Vevers, in a forthcoming paper, will report similarities between Aplysia and Akera in the possession of the pigment Uroporphyrin $\mathrm{I}$ in the integument.

Pelseneer's criterion of the separation of the lateral parapodial lobes from the ventral sole would seem a much less important character. In any event, 
this distinction is largely a matter of the particular height on the lateral surface at which the parapodia are given off. While creeping members of both suborders (like Philine and Aplysia) are equipped with a distinct sole, this character is surely an adaptive one, and it is likewise not surprising to find swimming members of both the Bullomorpha (Gastropteron) and the Aplysiomorpha (Akera) which have a very similar reduction of the creeping surface and enlargement of the parapodia. The parallel between Gastropteron and Akera is an instructive one, showing as it does the proneness of both these groups of tectibranchs to produce swimming members. Each group has further given rise to a section of the permanently swimming Pteropoda, the Bullomorpha producing the Thecosomata, and the Aplysiomorpha probably the Gymnosomata.

Two 'bullomorph' characters are generally relied on by those who would include Akera in the Cephalaspidea, namely the well-developed shell containing the mantle cavity with its pallial caecum, and the nervous system with its long visceral commissure still retaining the primitive torsion. Such features are each primitive ones: their possession implies not so much a close resemblance to the bullomorphs as a primitive position near the point where the aplysiomorphs sprang from basal tectibranchs. The pallial caecum is an elaborate structure following-independently of the visceral mass-a spiral course around the upper whorls of the shell. The earliest description was by Perrier \& Fischer (I9II), and Fretter \& Graham (I954) have recently given a detailed account of its structure and functioning in the primitive bullomorph, Actaeon tornatilis. This caecum was previously regarded as a bullomorph specialization, and its presence in an aplysioid is admittedly not easy to explain. Yet many difficulties disappear if we regard it not as a peculiarly bullomorph character, but as an adaptation likely to be found generally in those tectibranchs with a large mantle cavity, where a sedimented or silty habitat raises problems of pallial sanitation.

Guiart (I90I) gave a good description and figure of the nervous system of Akera bullata, and it is a pity that Pelseneer's later work (I906) entirely omitted mention of it. In reporting its streptoneurous condition, Guiart compares the nervous system of Akera with that of Actaeon. Undoubtedly Akera is much more primitive in the nervous system than any other aplysioid. It stands at the base of that group with much the same relationship to later Aplysiomorpha as Actaeon bears to later bullomorphs. Guiart finds in Akera certain characters of the nervous system in which this form already foreshadows the later aplysiomorphs. 'Il nous suffit de considérer un instant le système nerveux de l'Acera pour constater qu'il présente avec le système nerveux de Bulléens un certain nombre de modifications qui vont aller en s'accentuant chez les autres Aplysiens.'

The remainder of the family Akeratidae as recognized by Thiele cannot-it would seem-be placed with Akera in the Aplysiomorpha. Mr T. J. Evans 
(personal communication) informs one of us that Cylindrobulla and Volvatella are in fact saccoglossans. The different fates of the two subfamilies of Akeratidae is a good example of how-with better knowledge-the basal parts of more advanced groups may be found to encroach into the primitive group of Bullomorpha.

We are indebted to $\mathrm{Mr} \mathrm{M}$. Little of Plymouth for bringing our attention to the presence of Akera in the Devonport reservoir. A film of the swimming of Akera was taken by Mr F. A. J. Armstrong, upon which the diagrams illustrating the swimming movements (Text-fig. I) have been based. Dr D. P. Wilson kindly supplied the photographs reproduced in Pl. I.

\section{SUMMARY}

The tectibranch mollusc Akera bullata is recorded for the first time in the Plymouth area, where it was taken in April 1954 in a sea-water tank at Devonport. Large numbers of specimens of all sizes were present, and copulation and egg-laying were in progress. A summary is given of the records of previous occurrences in S.W. England, with ecological notes on the behaviour of the animal at Plymouth. The characteristic swimming movements of Akera occur mainly in the spring, and may be correlated with the breeding season. An account of the external form and structure is given and the mode of swimming is described in detail. The digestive system was investigated from Plymouth material, and the structure and mode of action of the alimentary canal described and shown to be typically aplysioid. The remaining characters of the animal, such as the structure of the reproductive organs, the pallial glands and the nervous system, also show aplysioid resemblances, and it is concluded that the family Akeratidae (in part) must be removed from the Bullomorpha and located more correctly in the Aplysiomorpha.

\section{REFERENCES}

Allen, E. J. \& Todd, R. A., I902. The fauna of the Exe estuary. F. Mar. biol. Ass. U.K., Vol. 6, pp. 295-335.

Bergh, R., I900. Tectibranchia, Lophocercidae, Ascoglossa. In: C. Semper, Reisen im Archipel der Philippinen. Wiss. Res., 7. Wiesbaden.

Clark, J., I906. Marine Zoology. The Victoria County History of the Counties of England: Cornwall, pp. I13-59. London.

Forbes, E. \& Hanley, S., 1853. A History of British Mollusca, and their Shells, Vol. 3, 6r6 pp. London: Van Voorst.

FreTtER, VerA, I939. The structure and function of the alimentary canal of some tectibranch molluscs, with a note on excretion. Trans. roy. Soc. Edinb., Vol. 59, pp. 599-646.

FretTer, Vera \& Graham, A., I954. Observations on the primitive opisthobranch Actaeon tornatilis. F. Mar. biol. Ass. U.K., Vol. 33, pp. 565-85.

Guiart, J., I90I. Contribution a l'étude des gastéropodes opisthobranches et en particulier des céphalaspides. Mém. Soc. zool. Fr., T. I4, pp. 5-219. 
Hoffmann, H., 1938. Bronn's Klassen und Ordnungen des Tierreichs. Mollusca, II, 3. Leipzig.

HowelLs, H. H., I942. The structure and function of the alimentary canal of Aplysia punctata. Quart. F. micr. Sci., Vol. 83, pp. 357-397.

Jefrreys, J. G., 1867. British Conchology, Vol. 4, 486 pp. London: Van Coorst.

Jukes-Browne, A. J., I9IO. Fauna and flora of the Torquay district. No. 2. Marine Mollusca. F. Torquay nat. Hist. Soc., Vol. I, pp. 68-73.

Marine Biological Association, 1931. Plymouth Marine Fauna (2nd ed.), 37i pp.

MILNE, A., I938. The ecology of the Tamar estuary. III. Salinity and temperature conditions in the lower estuary. F. Mar. biol. Ass. U.K., Vol. 22, pp. 529-42.

Montagu, G., I803. Testacea Britannica. Part I, pp. I-29I. London.

Norman, A. M., i890. Revision of British Mollusca. Ann. Mag. nat. Hist., Ser. 6, Vol. 6, pp. 60-9I.

Pelseneer, P., Ig06. Mollusca. In: A Treatise on Zoology, ed. E. Ray Lankester. $355 \mathrm{pp}$. London.

PerRIER, R. \& Fischer, H., I9II. Recherches anatomiques et histologiques sur la cavité palléale et ses dépendances chez les Bulléens. Ann. Sci. nat., Zool., Sér. 9, T. I4, pp. I-I89.

Station Biologique De Roscoff, I95I. Inventaire de la Faune Marine de Roscoff. Mollusques. Trav. Sta. biol. Roscoff, Suppl. 5, 80 pp.

ThIELE, J., I93I. Handbuch der systematischen Weichtierkunde. Vol. I, $40 \mathrm{I}$ pp. Jena.

Thorson, G., I946. Reproduction and larval development of Danish marine bottom invertebrates, with special reference to the planktonic larvae in the Sound (Øresund). Medd. Komm. Havundersøg., Kbh., Ser. Plankton, Bd. 4, No. I. $523 \mathrm{pp}$.

WinckWORth, R., I932. The British marine Mollusca. F. Conch., Vol. I9, pp. 2 I I-52.

\section{EXPLANATION OF PLATE I}

Swimming movements of Akera. I, 2, lateral view of swimming specimens, slightly less than natural size. 3 , a specimen, viewed from above, about to rise from the bottom of a dish. About twice natural size.

Photographs from Kodachrome originals by D. P. Wilson. 

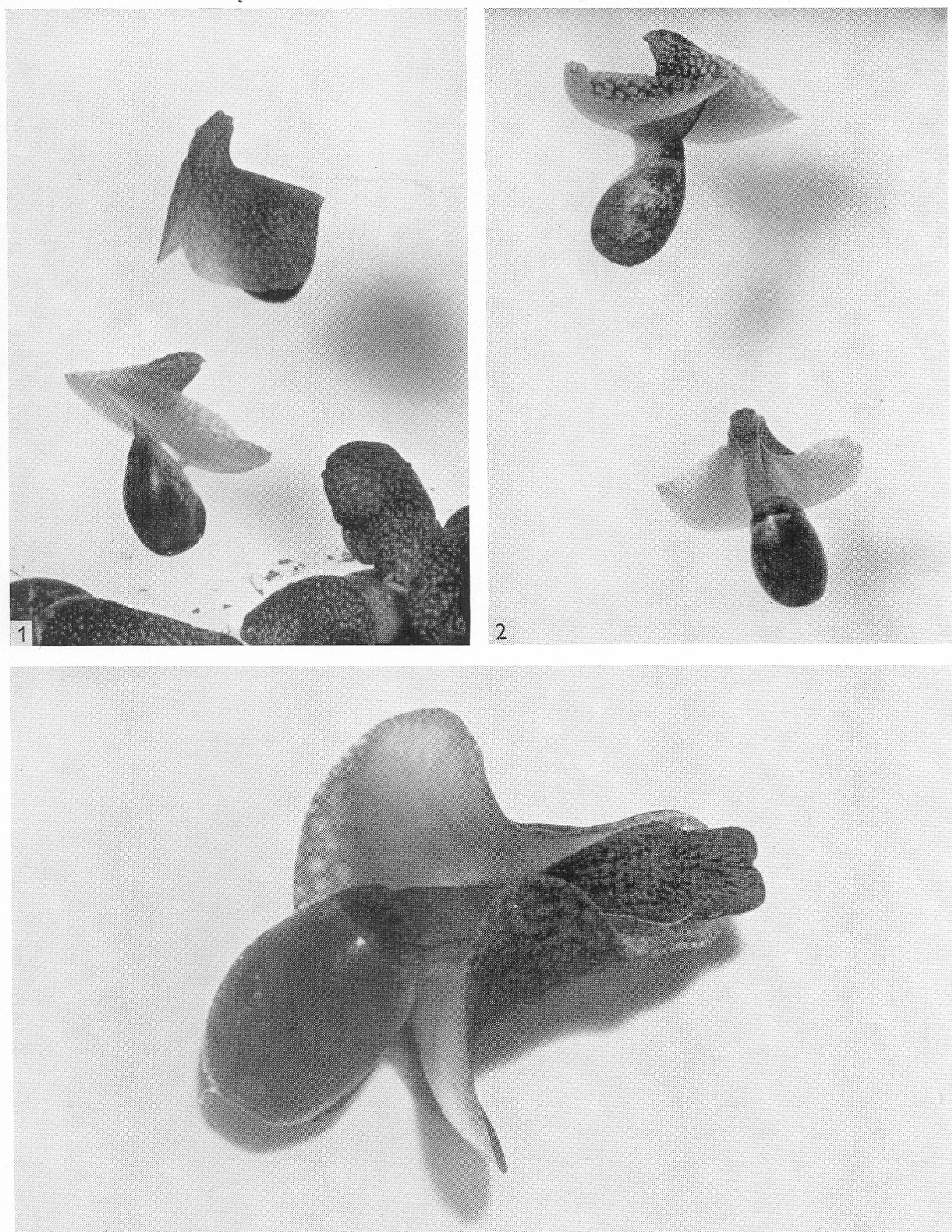